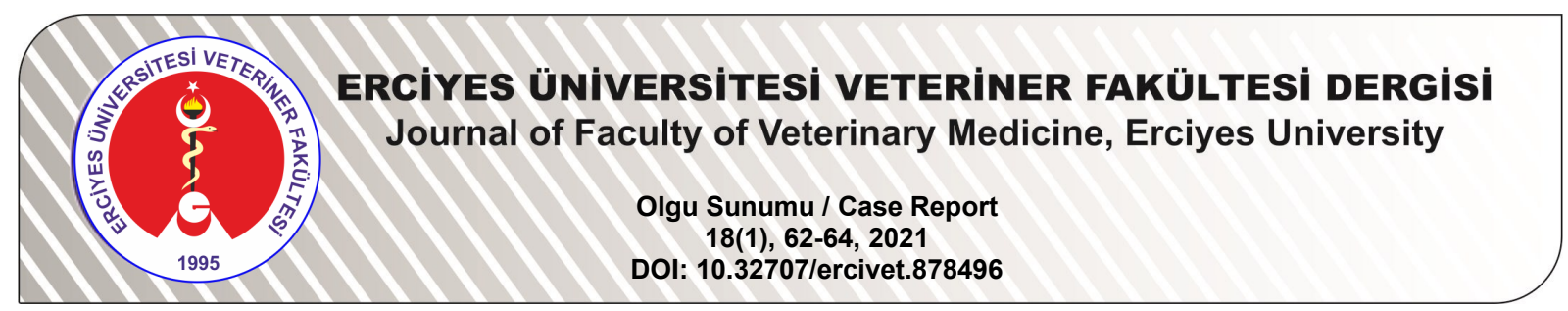

Neuronal Lipofuscinosis in a Hairy Goat*

\author{
Hamdi AVCI ${ }^{1}$, Sümbül Serap BiRinCiOĞLU², Erkmen Tuğrul EPIKMEN ${ }^{1}$, Ahmet AYDOĞAN ${ }^{3}$ \\ ${ }^{1}$ Aydın Adnan Menderes University, Faculty of Veterinary Medicine, Department of Pathology, Aydın-TURKEY \\ ${ }^{2}$ Special A Pathology Laboratory, Izmir-TURKEY \\ ${ }^{3}$ Çukurova University, Faculty of Ceyhan Veterinary Medicine, Department of Pathology, Adana-TURKEY
}

Corresponding author: Ahmet AYDOĞAN; E-mail: aaydogan@cu.edu.tr; ORCID: 0000-0003-2504-8150

How the cite: Avcı H, Birincioğlu SS, Epikmen ET, Aydoğan A. Neuronal lipofuscinosis in a hairy goat. Erciyes Univ Vet Fak Derg 2020; 18(1): 57-59

Summary: In the present case, neuronal lipofuscinosis was determined in a three-year-old female hair goat. The systemic necropsy was performed. Tissue sections were stained with hematoxylin and eosin (HE), periodic acid schiff stain (PAS), Schmorl's and long Ziehl-Neelsen (ZN) methods for lipofuscin; Turnbull's blue method for hemosiderin and melanin removal method II for melanin. Unstained deparaffinized sections were examined microscopically for fluorescence in transmitted ultraviolet light. In addition, samples of pons and medulla oblongata were collected and processed for transmission electron microscopy investigations. Macroscopically, the meninges were opaque and the cerebral hemispheres had firm consistency. Microscopically, pigment granules in varying intensity were observed in the cytoplasm of the neurons of the pons and medulla oblongata. Red or yellowish-brown grannules were usually seen in perinuclear localization, and filled all cytoplasm of some neurons. Moreover, meningeal and perineuronal edema, perivascular hemorrhage and neuronal degeneration were prominent histopatologic findings. The granules were positively stained with PAS, Schmorl's and long ZN methods, but negatively stained with Turnbull's blue method and melanin removal method II. Pigments found in all affected neurons were brightly autofluorescent. Electron microscopy also confirmed that the pigment granules were lipofuscin.

Key words: Neuronal lipofuscinosis, pathology, electron microscopy, goat

\title{
Bir Kıl Keçisinde Nöronal Lipofusinozis
}

Özet: Bu olgu raporunda, üç yaşlı, dişi bir kıl keçisinde görülen nöronal lipofusinozisin tanımlanması amaçlandı. Keçinin sistemik nekropsisi yapıldıktan sonra alınan doku örneklerinin kesitleri; lipofusin pigmenti için hematoksileneozin (HE), periodic acid-schiff (PAS), Schmorl's ve long Ziehl-Neelsen (ZN) boyama yöntemleri ile; hemosiderin için Turnbull blue ve melanin için melanin removal method II yöntemleri ile boyandıktan sonra ışık mikroskobunda değerlendirildi. Herhangi bir histokimyasal uygulama görmemiş preparatlar direkt olarak floresan mikroskopta; ayrıca pons ve medulla oblongata'dan alınan doku örnekleri elektron mikroskopta incelendi. Makroskobik incelemede, meninksler matlaşmış ve serebral hemisferler hafif sert kıvamlı idi. Mikroskobik incelemede, pons ve medulla oblongata'da bulunan nöronların sitoplazmalarında değişen yoğunluklarda kırmızı ya da sarı-kahve renkli pigment granülleri görüldü. Bu granüller sıklıkla perinüklear yerleşimli olup, bazı nöronlarda sitoplazmanın tamamını doldurmuştu. Pigment birikimi ile birlikte meningeal ve perinöronal ödem, perivasküler kanama ve nöron dejenerasyonu belirlendi. PAS, Schmorl's ve Long ZN boyama yöntemleri ile pozitif; Turnbull blue ve melanin removal method II boyama yöntemleri ile negatif boyanma özelliği gösteren pigment granüllerinin tamamı, floresan mikroskoptaki direkt incelemede floresan pozitif yansımalar verdi. Elektron mikroskobik incelemede de bu pigment granüllerinin lipofusin pigmenti olduğu doğrulandı.

Anahtar kelimeler: Nöronal lipofusinozis, patoloji, elektron mikroskopi, keçi

\section{Introduction}

Lipofuscin is primarily composed of cross-linked protein residues and is known as age related pigment due to lipid destruction in cell membranes with accumulation occurs as a result of long-term and continuous autoxidation of unsaturated lipid precursors. This pigment shows intralysosomal, perinuclear location and accumulates in cells and organs with high metabolic activity such as neurons, all muscle types, liver

\begin{tabular}{ll}
\hline Geliş Tarihi/Submission Date & $: 10.04 .2020$ \\
Kabul Tarihi/Accepted Date & $: 02.06 .2020$
\end{tabular}

*This case report was presented as a poster at the "6. National Congress of Pathology" in Aydın-TURKEY. and heart (Glees and Hasan, 1976; Cheville, 1983; Huxtable et al., 1987). It is not destroyed by the cell's proteolytic system, nor can it be removed from the cell by exocytosis. One of the most important features of lipofuscin is autofluorescence character in unstained sections by fluorescent microscope (Cheville, 1983). In light microscopic examinations, lipofuscin pigment shows irregular granular structures in colors ranging from golden yellow to dark brown in Hematoxylin and eosin (HE) stain (Carson and Hladik, 2009). In ultrastructural studies, it is seen as granules filled with vacuoles and lipid globules (Glees and Hasan, 1976; Cheville, 1983; Culling et al., 1985). 
In this case report, neuronal lipofuscinosis was firstly identified with pathological and electron microscopic findings in a hair goat (Capra hircus).

\section{Case}

A three-year-old, female, hair goat was presented to pathology laboratory for necropsy. The systemic necropsy of animal was performed. Tissue samples taken after necropsy were fixed in $10 \%$ buffered formalin, processed routinely and embedded in paraffin wax. Sections were cut at 5-6 $\mu \mathrm{m}$ thickness and stained with hematoxylin and eosin (HE). The selected sections were stained by the periodic acid schiff stain (PAS), Schmorl's, Oil Red O, Sudan Black B and long Ziehl-Neelsen (ZN) methods for lipofuscin; Turnbull's blue method for hemosiderin and melanin removal method II for melanin (Luna, 1968; Culling et al., 1985; Carson and Hladik, 2009). Unstained deparaffinized sections were examined microscopically for fluorescence in transmitted ultraviolet light (Olympus U-LH100-3). Samples of pons and medulla oblongata taken in $1 \mathrm{~mm}$ also collected and processed for transmission electron microscopy investigations. These tissue samples were fixed for 48 hours in a mixture of $5 \%$ gluteraldehyde and paraformaldehyde buffered with cacodilate. Then, it was washed with $1 \% \mathrm{M}$ cacodilate buffer ( $\mathrm{pH} 7.4)$ and post-fixed in $2 \%$ osmium tetraoxide. After being dehydrated in graded alcohols and passed through propylene oxide, it was blocked with Epon 812. Thin sections were stained with toluidine blue, and the areas selected from these sections were examined with Carl-Zeiss Em $9 \mathrm{~S}$ electron microscope after staining with uranyl acetate and lead citrate (Culling et al., 1985).

In the anamnesis, it was reported that the animal had difficulty in walking, and sometimes it could not displace. In addition, it was stated that tremors and convulsions, which started mildly, continued increasingly after a while. Macroscopically, the goat was in poor condition. The meninges were opaque and the cerebral hemispheres had firm consistency. No macroscopic findings were found in the visceral organs. However, it was noticed that tissues had a gelatinous appearance. In the histopathological examination, the light pink pigment granules in varying intensity and 2$10 \mu \mathrm{m}$ in size were observed in the cytoplasm of all neurons of pons and medulla oblongata (Figure 1A). These pigment granules were usually located perinuclearly, and they filled the entire cytoplasm in some neurons. Meningeal and perineuronal edema, perivascular hemorrhage and neuronal degeneration were prominent histopathologic findings together with pigment accumulation.

The pigment granules were stained positively with PAS (Figure 1B), Oil Red O, Sudan Black B, Schmorl's and long ZN staining methods, while they were negatively stained with Turnbull's blue method and melanin removal method II. All of the pigment granules which showed negative staining with other staining methods gave fluorescent positive reflections in direct examination under fluorescent microscope (Figure 1C). In the electron microscopic examination, pigment granules were localized in the pericarial cytoplasm of neurons and seen as irregularly shaped electron-dense structures ranging in size from 0.5 to $2.5 \mu \mathrm{m}$. Some of these structures were in the form of lobules or lamellae containing various sized vacuoles, while some of them were in the thin granular form surrounded by a membrane (Figure 1D).

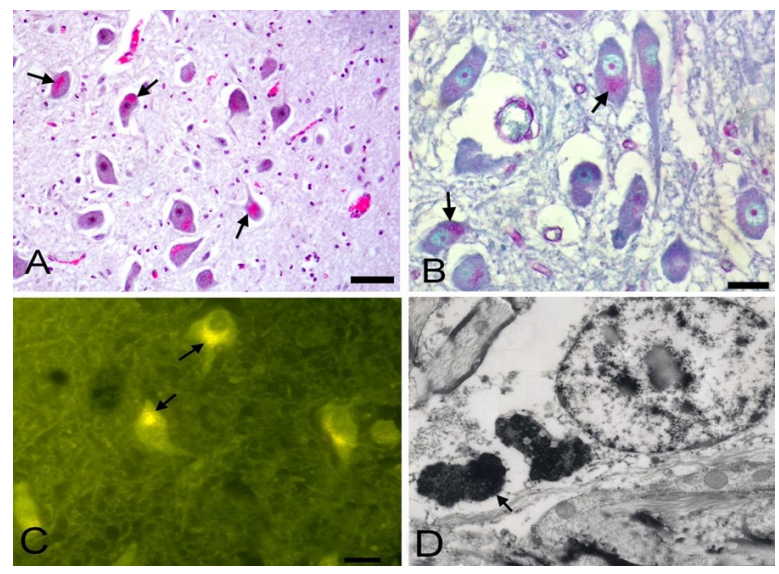

Figure 1. Neuronal lipofuscinosis. A. Light pink pigment granules in the cytoplasm of neurons (arrows), pons, H\&E, Bar $=30 \mu \mathrm{m}$ B. Pigment granules in the cytoplasm of neurons, pons (arrows), PAS, Bar $=30$ $\mu \mathrm{m}$ C. Fluorescent positive reflections under fluorescent microscope (arrows), Bar $=30 \mu \mathrm{m}$ D. Electrondense lipofuscin granules (arrow), electron microscope Ax 16000, Bx20000

\section{Discussion and Conclusion}

Lipofuscin pigment accumulates in different post mitotic cells like neurons and causes some neurologic disorders due to cellular dysfunction and degeneration (Baghban et al., 2013). Although neuronal lipofuscinosis has been identified in many animal species such as horses, cattle, cats and sheep (Huxtable et al., 1987; Jolly et al., 2002; Birincioğlu et al., 2005; Baghban et al., 2013), no literature information has been available regarding the occurrence in hair goats. Here, we report, to the best of our knowledge, the first case of neuronal lipofuscinosis in a hair goat.

Congenital enzyme deficiencies, toxicities, severe nutritional disorders, vitamin $\mathrm{E}$ deficiency, starvation due to cancer or radiation therapy and aging can be considered as the causes of accumulation of lipofuscin pigment (Huxtable et al., 1987; Birincioğlu et al., 2005; Wohlsein et al., 2013). In this presented case, it was thought that it may be related to both age of the animal and the long-term nutritional disorder in 
relation to the cause of the lipofuscin pigment defined only in the central nervous system. The anamnesis and gelatinous changes observed in the adipose tissue of other organs were supported this view.

Neuronal seroid lipofuscinosis should be considered in the differential diagnosis of neuronal lipofuscinosis. It is reported that histochemical stainings and electron microscopic examinations are the most common methods for distinguishing these two pigments (Culling et al., 1985; Nardocci and Cardona, 1998; Tammen et al., 2001; Jolly et al., 2002). Although lipofuscin pigment shows positive staining with PAS, Schmorl's, Oil Red O, Sudan Black B, Long ZN staining methods; seroid lipofuscin pigment shows negative staining with Schmorl's staining method (Culling et al., 1985; Carson and Hladik, 2009; Birincioğlu et al., 2012). In this report, the pigment granules were stained positively with PAS, Oil Red O, Sudan Black $B$, Schmorl's and long ZN staining methods. Even though electron microscopic examinations show the characteristic "fingerprint" lamellar structure in the lysosomes for seroid-lipofuscin pigment (Nardocci and Cardona, 1998), in this case, the pigment was seen in a vacuolar and lobular structure for lipofuscin pigment as reported in the literature (Glees and Hasan, 1976; Jolly et al., 1995). Moreover, negative staining was seen with Turnbull's blue method for hemosiderin and melanin removal method II for melanin.

Lipofuscin pigment accumulates cytoplasmically in cells of many organs and tissues such as central nervous system, liver, heart, kidney and intestines. This accumulation has been reported to be a yellowbrown color by many researchers in HE staining (Culling et al., 1985; Huxtable et al., 1987; Jolly et al., 2002; Birincioğlu et al., 2005; Carson and Hladik, 2009). In a case report, this pigment is stained slight eosinophilic and pale in HE method (Baghban et al., 2013). In this case, the pigment granules were stained strongly eosinophilic. This was thought to be related to the density of metals such as iron, copper, zinc, manganese and calcium bound to iron-binding proteins in the structure of the lipofuscin pigment (Jung et al., 2007).

In conclusion, in this case report, neuronal lipofuscinosis was identified with pathological and electron microscopic findings in a three-year-old hair goat.

\section{References}

Baghban F, Gharagozlou MJ, Bazargani TT, Samani R. Neuronal lipofuscinosis in an adult horse. Indian J Vet Pathol 2013; 37: 89-90.

Birincioğlu SS, Çalış I, Avcı H, Erdağ B. Pathological and phytochemical investigation of neuronal lipofuscinosis caused by Asphodelus aestivus in sheep: I. pathological findings. Turkish J Vet Anim

\section{Sci 2005; 29: 1351-6}

Birincioğlu SS, Schmahl W, Avcı H. Neuronal and extraneuronal lipofuscinosis in merino sheep grazing Asphodelus aestivus seeds in western Turkey. Turkish J Vet Anim Sci 2012; 36: 476-82.

Carson FL, Hladik C. Histotechnology, A SelfInstructional Text. Third Edition. Hong Kong: Academic Society for Clinical Pathology Press, 2009.

Cheville NF. Cell Pathology. Second Edition. Iowa: The lowa State University Press, 1983; pp. 153-8.

Culling CFA, Allison RT, Barr WT. Cellular Pathology Technique. Fourth Edition. London: Butterworth \& Co Publishers Ltd, 1985; pp. 278-88.

Glees P, Hasan M. Lipofuscin in neuronal aging and diseases. Bargmann W, Doerr W. eds. In: Normal and Pathological Anatomy. Stuttgart: Georg Thime Publishers 1976; pp. 1-58.

Huxtable CR, Chapman HM, Main DC, Vass D, Pearse BHG, Hilbert BJ. Neurological disease and lipofuscinosis in horses and sheep grazing Trachyandra divaricata (branched onion weed) in South Western Australia. Aust Vet J 1987; 64: 105-8.

Jolly RD, Douglas BV, Davey PM, Roiri JE. Lipofuscin in bovine muscle and brain: A model for studying age pigment. Gerontol 1995; 41 (2): 283-95.

Jolly RD, Arthur DG, Kay GW, Palmer DN. Neuronal ceroid-lipofuscinosis in Borderdale sheep. NZ Vet $\mathrm{J}$ 2002; 50 (5): 199-202.

Jung T, Bader N, Grune T. Lipofuscin: Formation, distribution, and metabolic consequnces. Ann NY Acad Sci 2007; 1119: 97-111.

Luna LG. Manual of Histologic Staining Methods of the Armed Forces Institute of Pathology. Third Edition. New York: Mc Graw-Hill Book Company, 1968.

Nardocci N, Cardona F. Neuronal ceroid lipofuscinosis: A review. Ital J Neurol Sci 1998; 19: 271-6.

Tammen I, Cook RW, Nicholas FW, Raadsma HW. Neuronal ceroid lipofuscinosis in Australian Merino sheep: A new animal model. Euro J Pediatr Neurol 2001; 5 (Suppl A): 37-41.

Wohlsein P, Deschl U, Baumgartner W. Non lesions, unusual cell types and postmortem artifacts in the central nervous system of domestic animals. Vet Pathol 2013; 50 (1): 122-43. 
